NBER WORKING PAPER SERIES

\title{
GEOGRAPHIC BARRIERS TO COMMODITY PRICE INTEGRATION: EVIDENCE FROM US CITIES AND SWEDISH TOWNS, 1732-1860
}

\author{
Mario J. Crucini \\ Gregor W. Smith \\ Working Paper 20247 \\ http://www.nber.org/papers/w20247
NATIONAL BUREAU OF ECONOMIC RESEARCH
1050 Massachusetts Avenue
Cambridge, MA 02138
June 2014

Crucini gratefully acknowledges the financial support of the National Science Foundation (SES-0524868). Smith thanks the Social Sciences and Humanities Research Council of Canada and the Bank of Canada research fellowship programme for support of this research. The opinions are the authors' alone and are not those of the Bank of Canada. The views expressed herein are those of the authors and do not necessarily reflect the views of the National Bureau of Economic Research.

NBER working papers are circulated for discussion and comment purposes. They have not been peerreviewed or been subject to the review by the NBER Board of Directors that accompanies official NBER publications.

(C) 2014 by Mario J. Crucini and Gregor W. Smith. All rights reserved. Short sections of text, not to exceed two paragraphs, may be quoted without explicit permission provided that full credit, including (C) notice, is given to the source. 
Geographic Barriers to Commodity Price Integration: Evidence from US Cities and Swedish

Towns, 1732-1860

Mario J. Crucini and Gregor W. Smith

NBER Working Paper No. 20247

June 2014

JEL No. F61,N70

\begin{abstract}
$\underline{\text { ABSTRACT }}$
We study the role of distance and time in statistically explaining price dispersion for 14 commodities from 1732 to 1860 . The prices are reported for US cities and Swedish market towns, so we can compare international and intranational dispersion. Distance and commodity-specific fixed effects explain a large share - roughly $60 \%$ - of the variability in a panel of more than 230,000 relative prices over these 128 years. There was a negative "ocean effect": international dispersion was less than would be predicted using distance, narrowing the effective ocean by more than $3000 \mathrm{~km}$. The absolute effect of distance declined over time beginning in the 18th century. This process of convergence was broadbased, across commodities and locations (both national and international). But there was a major interruption in convergence in the late 18th and early 19th centuries, at the time of the Napoleonic Wars, stopping the process by two or three decades on average.
\end{abstract}

\author{
Mario J. Crucini \\ Department of Economics \\ Vanderbilt University \\ Box 1819 Station B \\ Nashville, TN 37235-1819 \\ and NBER \\ mario.j.crucini@vanderbilt.edu \\ Gregor W. Smith \\ Department of Economics \\ Queens University \\ Kingston, Ontario \\ K7L 3N6, Canada \\ smithgw@econ.queensu.ca
}


"Stockholm therefore, for the purposes of the argument may be considered as within fifty miles of Philadelphia." -Daniel Webster, Philadelphia, 1824. ${ }^{1}$

\section{Introduction}

The Law of One Price (LOP) is the theoretical proposition that in the absence of official and natural barriers to trade, common currency prices of identical goods are equated. Deviations from LOP, so defined, represent unexploited gains from trade. It turns out to be almost impossible to test the proposition in this form since it requires both common currency prices of identical goods and also measures of official and natural barriers to trade in these same goods, which are typically more difficult to come by than the prices themselves.

Consequently, virtually all empirical work on the subject measures the deviations of common currency market prices of commodities across markets and then attempts to indirectly infer the contribution of official and natural barriers to their geographic variation. The most popular method is due to Engel and Rogers (1996). They computed the variance of LOP deviations for city pairs within the US, within Canada, and across the border and regressed this measure on the distance between the city pairs and a dummy variable that takes the value one if the cities lies on opposite sides of the US-Canada border. Using 15 sub-indices of the CPI across 14 US and 9 Canadian cities, from 1978 to 1994, they found that the border crossing added an economically significant amount of price dispersion over and above the estimated effect of geographic distance. In particular, the implied width of the border was estimated to be an astonishing 75,000 miles. $^{2}$

This paper adapts the Engel-Rogers method to study deviations from the LOP within

\footnotetext{
${ }^{1}$ This is a stylized version of the Congressional record. According to Taussig (1892) the statements related to this quote, which took place during Congressional debates on proposed tariff legislation in 1824, were: "the US should accept vast multitudes of persons willing to labor in the production of articles at the rate of 7 cents per day when our labor is five or six times that level and thus leave our labor to other manufacturers to earn its greater reward rather the impose a tax on consumers to produce goods similar to that which are presently imported from Sweden," and that "the money required to ship one ton of merchandise by ocean freight from Stockholm to Philadelphia could alternatively be used to purchase about fifty miles of overland transport from Philadelphia to points inland."

${ }^{2}$ This estimate has been subject to both criticism and revision as discussed further below. However, large positive border effects remain typical in post World War II era estimates.
} 
and across the United States and Sweden during a much earlier historical period, 1732-1860. The choice of Sweden is due to the availability of market prices spanning a similar time span and commodity set to what exists in the Cole data archive for the US, described in more detail below. What is interesting about the quote from Daniel Webster (above) is that it implies that the economic width of the border (or, perhaps we should say, the width of the ocean) in the early 1800's was a large negative number. If Webster's estimate is of the correct sign, it suggests a dramatic increase in the impediments to international trade relative to intranational trade from the 18th century to the present day. Thus, our goal in this paper is to shed light on the impediments to trade within and across countries in historical times by studying what is arguably the best available panel of micro-price data currently available, spanning the years 1732 to 1860, 14 commodities, and 38 locations.

The U.S. data was originally published in the Statistical Appendix to the volume edited by Arthur Harrison Cole (1938). The data span 6 cities: Boston, Charleston, Cincinnati, New Orleans, New York and Philadelphia. Charleston, New Orleans and Cincinnati are important for us because of their distance from the 3 cities in the northeast and the fact that Cincinnati was a developing region in the early stages of westward migration. The Swedish micro-price data archive is drawn Lennart Jörberg (1972) who led a team of Swedish researchers. They studied a total of 32 towns or regions at various times. Reflecting the objectives of our study, we collected annual prices from the Swedish historical sources for commodities that are closely matched to the goods also found in the Cole micro-archive: bar iron, beef, butter, copper, hops, pig iron, pork, salt, saltpetre, tallow, tallow candles, wax candles, wheat and wool.

We have two sets of results. The first set of results averages the price deviations across time to address two related questions. The first asks what role geographic distance plays, in sustaining price deviations across cities, over the long-term. The second question we ask is what, if any, role is played by the ocean after controlling for distance between cities. This analysis is aimed at estimating time-invariant barriers to trade that are expected to increase 
with distance (such as shipping cost and freight insurance) as well as the possibility that these costs are different for movements of goods by land and by sea.

On average, over the sample, $1000 \mathrm{~km}$ of distance adds about $6 \%$ to the median absolute deviation of relative prices. The effect ranges from a low of $2.76 \%$ for wheat to a high of $20 \%$ for butter, indicating some caution in extrapolating from existing studies of the global wheat market to the broader commodity basket. The ocean effect is indeed negative as Webster surmised. The effective distance between Stockholm and Philadelphia was $2884 \mathrm{~km}, 3561$ $\mathrm{km}$ less than the great circle distance of $6445 \mathrm{~km}$. Thus, the estimated width of the ocean is $-3561$.

The second set of results allow the quantitative role of distance and the ocean in sustaining price deviations to change over time. There are a number of reasons to expect this to occur. Historians have emphasized secular declines in trade costs as possible explanations for both intranational and international commodity price convergence. The modern international finance literature has argued that currency arrangements and business cycles may lead to large and persistent deviations in prices from their long-run parities. There were also a number of obvious disruptions to trade and commerce over this period, the Seven Years War, the Revolutionary War, wars between Sweden and Russia, a trade embargo on British goods initiated by Thomas Jefferson, as well as British and French naval blockades during the Napoleonic Wars.

Price dispersion is estimated to be falling gradually over time with a brief reversal during the War of 1812. Evidently this decline is not due to a fall in the marginal cost of shipping since we fail to find a systematic decline in the slope coefficient on distance in our analysis. Rather, the declines are captured through fixed time-effects. Since the time effects are estimated with less precision than either the distance or ocean effects, additional data may be necessary to reaffirm this finding. One possible explanation for the decline in price dispersion consistent with its not interacting with distance is the process of development. That is, as locations in the hinterlands (such as Cincinnati) develop over time their price 
levels may converge toward the levels in major, developed, cities even in the absence of a downward trending marginal cost of shipping.

\section{Related Research}

Our goal is to study the geography of price dispersion both internationally and intranationally, back to the 18th century and using a range of commodities. While we are not aware of directly comparable work for this time span, we can draw on a wealth of recent research that provides benchmarks. This work looks at the extent of price convergence between locations, its evolution over time, and the causes of and obstacles to that convergence. Jacks, O’Rourke, Williamson (2011) provide a broad review of this literature.

First, several studies assess the LOP internationally. For example, Rogoff, Froot and Kim (2001) describe the price differences between London and Amsterdam for 7 commodities over many centuries. O'Rourke and Williamson (1994) study 13 commodities traded between the US and UK from 1870 to 1913, and report a convergence trend. Klovland (2005) studies 39 commodities in Britain and Germany for a similar period, from 1850 to 1913, and again studies the persistence of LOP deviations.

Second, several studies examine LOP deviations intranationally. For example, Dobado and Marrero (2005) document how corn prices converged across 32 Mexican states from 1885 to 1908. Trenkler and Wolf (2005) study wheat flour prices across Polish cities in the interwar period. The work of Slaughter (1995) is of particular relevance to our study, as he studies prices in the 19th-century US. He finds annual averages for 1820-1860 for 10 goods in the Cole data and describes how prices across cities tended to converge over time. And he describes the roles of canals, steamboats, and railroads in the convergence.

Third, a number of studies compare international and intranational price dispersion but for a single commodity: wheat. Studying wheat has four distinct advantages: (a) it is storable (and was so historically); (b) it is internationally traded; (c) in some cases its price is recorded according to standardized varieties; and (d) in some cases shipping costs 
can be collected. These features suggest that arbitrage could operate, with the passage of time, as emphasized by Pippenger and Phillips (2008) in their study of wheat prices in the late 20th century. Shiue (2005) describes the differences in grain prices across cities in Germany and its neighbors as the zollverien customs union spread between 1815 and 1855. She compares these differences with those between German and non-German cities and finds a small border effect. Keller and Shiue (2008) use annual wheat prices for the 19th century in 68 central European cities, mostly in Germany, to investigate the conduits for price convergence. Jacks (2004, 2005, 2006, 2009) examines wheat prices for a wide range of time periods and cities. For example, Jacks (2005) studies the period 1800-1913 for up to 100 cities in 10 countries including the US, where quotations come from up to 11 cities. He documents price convergence using several different statistics. Jacks also discusses the causes of convergence and the impediments to it. He considers such factors as transport costs, other transactions costs or improvements such as the rise of bills of exchange, price manuals, marine insurance, the effects of wars, and mercantilist policy (such as the 17th century Navigation Acts in Britain). He also compares trade costs for wheat to price differentials, finding that the differentials are up to twice as large as reported trade costs. He also regresses measures of price dispersion on variables such as distance, exchange-rate volatility, and dummy variables for borders, port and railway status, or a common currency. He finds a positive effect of borders and a negative effect of water transport, as well as declines in the effects of both distance and border-crossing over time. Jacks observes that the secondary literature on the US suggests that there was considerable convergence in prices internationally, but not intranationally, in keeping with Webster's suggestion. We can directly make this comparison for 14 commodities.

Several key studies also document interruptions in the process of convergence. Jacks (2011) documents the increase in commodity price dispersion within England during the Napoleonic Wars. He cites sources on the international effect of the wars as interrupting and then reversing commodity-market integration. He studies 4 grain prices in 52 counties 
from 1771 to 1815 and shows that intranational dispersion also increased. Jacks, O'Rourke, and Williamson (2011) study historical and contemporary data sources since 1700. They also document the increases in price volatility during 1776-1819 when trade in the Atlantic economies was disrupted by the Revolutionary War and the French Wars.

\section{Commodity Price Data}

The commodity price data used here are drawn from original sources. Each source consists of an extensive panel of local currency prices of individual commodities sold in different locations with the United States and Sweden. We supplement this data with data on the great circle distances between locations.

The U.S. panel data is taken from Cole (1938). The volume summarizes a number of independent scholarly efforts on US price history under the auspices of the International Scientific Committee on Price History, funded by the Rockefeller Foundation. While this data is not exhaustive of the commodity price data available for the US, it is the single largest collection of such data in terms of commodity, city and time span. ${ }^{3}$ The commodity price data were drawn mostly from newspapers and business accounting records and invoices. The frequency of the data is monthly; spanning 46 goods and six cities: Boston, Charleston, Cincinnati, New Orleans, New York and Philadelphia. In total there are 549 varieties of goods, ranging from 26 varieties of cotton to 2 types of potash. Each city's prices were compiled by or under the direction of a different researcher.

Jörberg (1972) describes the Swedish price data, which apply to 32 towns or regions at various times and to many commodities. For some commodities quality could vary from county to county, though goods were supposed to be of sufficient quality to satisfy payments due in kind. Scholars have used them to study the cost of living and real wages, but apparently not LOP deviations. The numbers come from market price scales that were used for taxes, tithes, and other payments. The prices were averages of current annual prices

\footnotetext{
${ }^{3}$ The details of data collection, unit conversions and monetary arrangements are elaborated in a companion Data Appendix to this paper.
} 
in market towns within each region.

One of our goals is to put US price dispersion in context by comparing US prices with those in a European country. We chose Sweden because its data overlap with those from Cole in both time span and commodity composition is greater than for other countries. Other potential sources of price data exist because of the work of the International Scientific Committee on Price History in the 1930s and 1940s, described by Cole and Crandall (1964). These sources include the monographs by Posthumus (1946) on Holland, Elsas $(1936,1949)$ on Germany, Hauser (1936) on France, Hamilton (1947) on Spain, and Pribram (1938) on Austria. The Danish price history project begun by Friis and Glamann (1958) is another rich source. But data for these countries involve significantly less overlap with the US data in terms of matching commodities or years and fewer intranational locations. Coincidentally, the Swedish data also allow us to assess Daniel Webster's observation.

Table 1 presents the commodities that we have matched across the US and Swedish archives, along with the units of measure and the number of bilateral city pairs available. The commodity list includes six agricultural commodities (beef, butter, hops, pork, wheat and wool), five non-agricultural commodities (bar iron, copper, pig iron, salt and saltpetre) and three candle-related commodities. ${ }^{4}$ This mix of foodstuffs and manufactures is typical of price history datasets.

Since the number of cities in the US archive is 6 and the number of towns in Sweden is 32, the maximum number of location pairs are 15 within the US, 496 within Sweden and 192 internationally. Given the historical period, it is not surprising that the number of available location pairs differs substantially by commodity, ranging from a high of 480 for butter in Sweden to a low of 2 for tallow candles in the United States.

We turn, now, to the time dimension of the sample to provide some historical context to the analysis and explain how we convert prices to common currency units in pounds sterling.

\footnotetext{
${ }^{4}$ Tallow is rendered beef or lamb fat processed from suet, it is solid at room temperature and was used to make candles as an alternative to wax.
} 


\section{Monetary and Exchange Rate History}

During our historical period of study, a number of remarkable changes in monetary arrangements took place. In the earliest part of the sample, US prices are quoted in units of Colonial currency. The individual Colonial governments issued fiat currency which they used to pay expenses, often of armed conflicts, and accepted as payment for taxes. Colonial currencies were also used in everyday transactions, though they did not serve as the exclusive medium of exchange. The Spanish silver dollar circulated widely, particularly in Charleston, Cincinnati and New Orleans, until the US silver dollar was first minted in 1792. Prices quoted in USD quickly emerge and come to dominate the Cole data by the early 1800s. Thus, to convert commodity prices into common currency units we need sterling exchange rates for each of the following media of exchange: individual Colonial currencies, the Spanish silver dollar and the US silver dollar.

From 1732 to 1775, we use the Handbook, McCusker (1978), which provides monthly exchange rates of Colonial currencies into pounds sterling. ${ }^{5}$ For example, the conversion from Pennsylvania pounds to pounds sterling is:

$$
\frac{P A \text { pounds }}{\text { metric unit }} \times \frac{1}{P A \text { pounds } / £}=\frac{£}{\text { metric unit }} \text {. }
$$

The price quotes in pounds after 1775 are not spanned by McCusker's exchange rate tables. For these observations, we use the exchange rates Cole provides for Colonial currencies in terms of the Spanish silver dollar. ${ }^{6}$ At inception, the US silver dollar was declared equal in value to the Spanish silver dollar. The official mint parity of sterling to the Spanish silver dollar was 4.444 Spanish silver dollars per pound sterling. Thus currency conversions

\footnotetext{
${ }^{5}$ These tables have missing observations. To fill in months that are missing exchange rates, we use the first exchange rate available preceding the month with no data. All prices in the original Cole data are assumed to be quoted in local colonial pounds.

${ }^{6}$ These rates are in a table on page six of his statistical appendix. The date ranges of the Cole data that require currency conversions are: i) Boston (1776-1798); ii) Charleston (1780-1812); iii) New Orleans (1805-1824); iv) New York (1776-1797) and v) Philadelphia (1784-1805). Unfortunately we have no solution for converting local currency prices in Charleston that occurred during the revolutionary war $(1776-1783)$. Those observations are dropped from the sample.
} 
between 1776 and 1791 are accomplished as follows:

$$
\frac{P A \text { pounds }}{\text { metric unit }} \times \frac{\text { Spanish silver dollar }}{P A \text { pounds }} \frac{1}{4.444 \text { Spanish silver dollars } / £}=\frac{£}{\text { metric unit }} \text {. }
$$

From 1792 onward, prices quoted in USD are converted to sterling prices using the annual GBP/USD exchange rate series originally assembled by Officer (2006):

$$
\frac{U S \text { silver dollar }}{\text { metric unit }} \times \frac{1}{U S \text { silver dollar } / £}=\frac{£}{\text { metric unit }} .
$$

Sweden adopted a series of unusual monetary arrangements during the 18th century. From 1732 to 1775 prices are quoted in silver dalers (daler silvermynt) (with unit öre, with 32 per daler). ${ }^{7}$ From 1776 to 1802 they are quoted in riksdaler specie (with units shilling, with 48 per riskdaler). During this period there were two internal units of account: riksdaler banco and riksdaler riksgälds, that had a varying relative value. Jörberg (1972, p 79) notes that market price scales were quoted in riksdaler riksgälds. After 1803 all prices are in kronor (singular: krona) per metric unit. Weights and measures also varied over time.

To express prices in common units over time we take two steps. First, we convert weights and measures to common metric units using Jörberg's guide (1972 p 95). After this step, prices are quoted in daler silvermynt for 1732-1775, riksdaler riksgälds for 1776-1802, and kronor for 1803-1860. Second, we then use the historical exchange-rate series assembled by the Sveriges Riksbank to convert each of these prices into pounds sterling. ${ }^{8}$ Their series for 1732-1775 is quoted in daler kopparmynt per pound sterling.

As each such coin was worth one-third of a daler silvermynt we calculate prices as follows:

$$
\frac{\text { daler silvermynt }}{\text { metric unit }} \times 3 \times \frac{1}{\text { daler koparmynt } / £}=\frac{£}{\text { metric unit }}
$$

Their series for 1776-1803 is quoted in riksdaler banco per pound sterling. The Riskbank also provides a series on the internal exchange rate between riskdalers banco and riskgälds,

\footnotetext{
${ }^{7}$ For several items the prices were fixed between 1735 and 1756. At that point they were unfrozen because the state was losing revenue due to inflation. Prices were collected at Thomasmäss (December 21) each year. But then in 1775 the officials were allowed to forecast prices for grains over the next few months if they thought the Thomasmäss price was abnormal. The time of the year for collection was changed to November in 1803. The coverage and averaging across districts within a county changed several times. Jorberg (1972, page 12) summarizes the various refinements over time.

${ }^{8}$ We obtained this at: www.riksbank.com/templates/Page.aspx?id=27399.
} 
so we calculate prices as follows:

$$
\frac{\text { riksdaler riksgälds }}{\text { metric unit }} \times \frac{\text { riskdaler banco }}{\text { riksdaler riksgälds }} \times \frac{1}{\text { riskdaler banco } / £}=\frac{£}{\text { metric unit }} \text {. }
$$

Their external exchange-rate series for 1803-1861 is quoted in kronor per pound, so we calculate prices as:

$$
\frac{\text { kronor }}{\text { metric unit }} \times \frac{1}{\text { kronor } / £}=\frac{£}{\text { metric unit }} \text {. }
$$

Each of these series is available annually, with two exceptions. The Riksbank provides the banco/riskgälds exchange rate and the kronor/sterling exchange rates at monthly frequency. We calculated prices in sterling first using annual averages for these two series and then again using the December values prior to 1803 and the November values after that, reflecting the months in which the market price scales were recorded.

Having converted prices to common currency (pounds sterling) and physical units, we are in a position to construct price indices and relative price levels for a common commodity basket using our archival data. The Laspeyres formula to construct price indices from common currency commodity prices, $P_{i, j, t}$ is:

$$
P_{j, t}=\frac{\sum_{i} P_{i, j, t} V_{i, 0}}{\sum_{i} P_{i, j, 0} V_{i, 0}}=\sum_{i} s_{i, 0} \frac{P_{i, j, t}}{P_{i, j, 0}}
$$

where $P_{i, j, t}\left(V_{i, j, 0}\right)$ is the price (quantity) of commodity $i$ in city $j$ and year $t$ and the zero denotes a choice of base year. The second expression expresses the price index as the expenditure-weighted average of price ratios (current prices relative to base prices). The expenditure weights $\left(s_{i, 0}\right)$ are are common across locations, time-invariant and measured at a base year (see the Appendix for further details).

Figure 1 shows the price levels (in units of pounds sterling) from 1732 to 1860 in Stockholm and Philadelphia with the commodity price level in Stockholm normalized to 100 in 1733. The most striking feature of the price levels is how closely they appear to follow common inflationary and deflationary trends. Moderate inflation during the 18th century is followed by a pronounced acceleration during the Napoleonic Wars, particularly in Stock- 
holm. The price levels drop suddenly at the end of the Napoleonic Wars, and inflation does not re-emerge in a systematic fashion until the 1830s.

A more direct measure of the extent to which price levels are equated in common currency units is the real exchange rate, which we define as the ratio of the price level in Stockholm $\left(P_{S, t}\right)$ relative to Philadelphia $\left(P_{U, t}\right):$

$$
Q_{S, U, t}=\frac{P_{S, t}}{P_{U, t}}
$$

Figure 2 plots the real exchange rate, the price level in Stockholm relative to Philadelphia. As might be inferred from figure 1, prices were typically lower in Philadelphia than in Stockholm. What is surprising in light of contemporary research on the topic is the lack of an obvious trend in the real exchange rate. Long-run purchasing power parity appears to hold, at least when confined to this common basket of commodities. More in line with 20th century evidence, we see large and persistent deviations from parity. Two obvious exceptions arise from very sharp declines in commodity prices in Stockholm that drive the relative price in Philadelphia from modestly lower than Stockholm to a multiple of the price level in Stockholm. These episodes are as short-lived as they are dramatic, with parity being re-established in the following year. The other notable episode is a large and highly persistent swing in the real exchange rate in the early 1800s with US commodities declining in relative price by almost $100 \%$ and then rising in relative price by about the same amount as the Napoleonic Wars draw to an end.

Figures 3 and 4 present prices of beef and wheat for all cities in the panel. The pairing of the US and Sweden is non-standard given the volume of trade between the two countries was quite small. And while both countries traded with England, international trade in these particular commodities overall was also quite small, particularly at the start of our sample period. Despite the moderate trade linkages as measured by the volume of trade, figures 3 and 4 show that there was indeed a shared international component to commodity prices.

As was true of the price levels, there are periods in which prices move in a very idiosyncratic fashion. The case of beef prices in Sweden during the Napoleonic Wars is illuminating. 
There is a five-fold increase in beef prices at the start of the conflict, which completely dwarfs the movements in prices of other goods in either country. That is, the price of beef in Sweden rises relative to everything else: to wheat in Sweden, beef in the US and wheat in the US. This example makes clear that we need to allow for the possibility that major historical events such as wars and trade embargoes result in large persistent deviations from the LOP. Furthermore, it may be that the impact is heterogenous across commodities. For example, a trade embargo would be expected to increase the price of imported goods and reduce the domestic price of goods that are exported.

\section{Geographic Barriers to Commodity Price Integration}

The Law of One Price is the theoretical proposition that, in the absence of natural and official barriers to trade, identical goods will sell at exactly the same price when converted to common units. Having converted all of our local currency units into pounds sterling and common physical units of measure, we are in a position to consider this proposition.

Our analysis proceeds in two stages. First we consider time invariant barriers, conceptually, the notion that distance between cities is constant and gives rise to a constant wedge between source and destination prices. The width of the ocean is the notion that the wedge is either greater or less depending on which mode of transportation is less costly. Second, we consider the possibility that the economic impact of distance changes over time. Obvious candidates are improvements in transportation technology that reduced the cost per kilometre of shipments. Less obvious, but also plausible, is the notion that expansions of the transportation network gave rise to new trading linkages where trade costs were initially prohibitive.

When the focus is time-invariant barriers, we work with the median of the absolute value of LOP deviations, where the median is taken over all time periods for which the bilateral relative price observations are available. Begin with the log relative price:

$$
q_{i, j k, t} \equiv \ln P_{i, j, t}-\ln P_{i, k, t}
$$


for good $i$ between locations $j$ and $k$. Formally, the time-varying measure then is defined as:

$$
a q_{i, j k, t}=100\left|q_{i, j k, t}\right|,
$$

while taking the median over time gives the time-invariant measure,

$$
\operatorname{mdaq}_{i, j k}=\operatorname{median}_{t}\left(a q_{i, j k, t}\right) .
$$

In each sub-section of our analysis we present both pooled and good-specific results. This is important for three reasons. First, much of the historical literature focuses on grain prices and since wheat is one of our commodities the disaggregated analysis provides a point of contact with an existing literature. Second, since the question of interest is market integration broadly defined, it is important to know if results for wheat hold for other commodities in the cross-section. Third, pooling enables us to estimate parameters more precisely and to broaden the time period and geographic scope of the analysis relative to a study focused exclusively on a single commodity.

\subsection{Time-Invariant Trade Barriers}

The empirical trade literature provides robust evidence of a negative relationship between bilateral trade volumes and the distance separating country pairs. The structural basis of this relationship is a gravity model of trade where the product of the economic mass of the two countries increases the propensity to trade while trade costs (proxied by distance) reduce that propensity. Head and Mayer (2013) provide a meta-analysis of the empirical work on the relationship between distance and border and bilateral trade volumes.

The historical literature has tended to focus on international relative prices where economic theory places directly testable restrictions. In contrast, the relationship between the volume of trade and trade costs depends on the elasticity of substitution between home and foreign goods. Specifically, our work follows a popular approach first developed by Engel and Rogers (1996) who studied real exchange rates across 14 U.S. and 9 Canadian cities. They computed the time series variance of bilateral real exchange rates for each city pair 
and estimated the following regression equation:

$$
v_{i j k}=\alpha_{i}+\beta_{d} \ln \left(d_{j k}\right)+\omega_{o} D_{j k}+\sum_{m=1}^{n} \omega_{i m} D_{m}+\epsilon_{i j k}
$$

where $v_{i j k}$ is the standard deviation of the two-month change in the logarithm of the bilateral real exchange rate for sub-index $i$ across city pair $j$ and $k, d_{j k}$ is the great circle distance between locations $j$ and $k$, and $D_{j k}$ is a dummy variable taking the value 1 if the locations are in different countries. $D_{m}$ is a dummy variable equal to 1 if city $m$ is included in the computation of the variance. The implied border effect in units of distance is: $\exp \left(\widehat{\omega}_{o} / \widehat{\beta}_{d}\right)$. Their baseline estimate of the Canada-US border was 75,000 miles.

We modify the equation specified by Engel and Rogers to reflect two problems pointed out in the subsequent literature and two amendments of our own. The first problem, pointed out by Parsley and Wei (2001) is that the implied width of the border is not invariant to the units in which distance is measured. The second problem, pointed out by Gorodnichenko and Tesar (2009) is that the width of the border depends on the intranational point of reference. For example, dispersion is lower within Canada compared to within the United States, after controlling for distance is each case, so that the border appears larger when extrapolated from Canadian price dispersion than when the US is the benchmark. The first problem is solved by moving the dummy variable into the logarithm function. The second problem is solved by adding a dummy variable for one of the two intranational location pairs.

We make two additional modifications. The standard deviation is replaced by the mean absolute deviation in the computation of real exchange rate volatility to mitigate sensitivity to outliers as may arise due to measurement error. Second, the city fixed-effects are replaced with good fixed-effects. In the context of this historical study using micro-data, good-specific fixed effects are more compelling. A third modification would be to study actual travel distances and shipping costs. Unfortunately neither of these types of data are available for the locations and time period of our study. Work in progress by Hung (2014) suggests a high correlation between great circle distance and minimum cost routes in the United States. 
The modified specification is thus:

$$
m d a q_{i, j k}=\alpha_{i}+\beta_{d} \ln \left(d_{j k}+\omega_{o} D_{j k}^{o}+\omega_{s} D_{j k}^{s}\right)+\epsilon_{i, j k} .
$$

$D_{j k}^{o}$ is a dummy variable taking the value 1 if the locations are in different countries ( $o$ is for ocean to indicate the most obvious geographic barrier between the United States and Sweden) and $D_{j k}^{s}$ is a dummy variable taking the value 1 if both locations are in Sweden.

Figure 5 presents the mean absolute deviation plotted against bilateral distance in kilometers, with US city pairs in the left panel, Swedish town pairs in the middle panel and international location pairs in the right panel. An upward sloping curve is evident in each panel. This is most visible when looking at the lowest levels of dispersion at each distance in the middle panel. Also apparent is the fact that the last panel does not exhibit substantially more price dispersion than the first two. Given the much greater distances on the axis of the international pairs due to the ocean, it appears that extrapolation from the intranational relationships would over-predict international price dispersion, a negative ocean effect consistent with Daniel Webster's oratory.

Table 2 reports the pooled regression results with coefficients on distance and the ocean constrained to be the same across commodities (these restrictions are relaxed in table 3). Estimation is by non-linear least squares. The row of results labelled $\alpha_{i}$ allows each commodity to have a different constant term in the regression (not reported) whereas the row labelled $\alpha$ forces all regressions to have the same constant term. The restriction on the constant does not appear to measurably affect the coefficients, though these intercepts are clearly important since the fraction of variance explained drops from $75 \%$ to $21 \%$ when a common intercept is imposed. Standard errors are robust to heteroskedasticity (found using method $\mathrm{HC} 2$ ). We also constructed standard errors based on clustering by distance (or, equivalently, by location pair) to be sure we did not overstate the precision by ignoring error correlation for a given location. The clustered standard errors were very similar to the traditional heteroskedasticity-consistent ones and so are not shown.

Table 2 shows the results of estimating equation (5.5) with 3607 observations on 14 
commodities, 6 US cities, and 32 Swedish towns. Consistent with the visual impressions of figure 5, distance is statistically significant and the ocean effect is negative. The fact that price dispersion is rising in distance is consistent with research studies that use modern data whereas the negative ocean effect contrasts with the positive border effects.

Turning to specifics, the estimates of $\widehat{\beta}_{d}$ show that distance is statistically significant at the $1 \%$ level. The coefficient on the ocean dummy variable is negative which implies that, after controlling for distance, shipping goods across the ocean was less expensive than shipping goods overland. Since distance is measured in kilometers, and the functional form is chosen so that $\widehat{\omega}_{o}$ is in the same units, the coefficient on the dummy variable that measures the width of the ocean is also in kilometers. Thus, on average, the ocean had the effect of reducing the land travel distance by 3761 kilometers $\left(\widehat{\omega}_{o}\right)$, with a $95 \%$ confidence interval of $(3065,4457)$ kilometers. In turn, this implies that the effective distance between Stockholm and Philadelphia was $2884 \mathrm{~km}$ (6445 km less the estimated impact of the ocean) with a $95 \%$ confidence interval of $(3380,1988)$. Thus we are able to validate Webster's estimate that ocean shipping costs were less than overland equivalents, but apparently not his guess at the magnitude. That is, our interval does not include the 50 miles $(80 \mathrm{~km})$ mentioned by Webster.

Finally, $\widehat{\omega}_{s}$, the coefficient on the intra-Sweden dummy variable is positive and significant at conventional levels. The interpretation is that price dispersion within Sweden was higher than one would expect given intra-US price dispersion, so that effective distances using the US as the benchmark exceeded actual geographic distances between Swedish market towns.

While the commodities are relatively standard it is worth noting what the effect would be of a difference in varieties that was systematic between the United States and Sweden over the time period. Suppose for example that Swedish copper was of higher quality than American copper and so sold at a higher price. The international relative price differences would then be larger than otherwise, as would their medians. This measurement error would then tend to make the ocean effect positive. Since we find a large, negative ocean effect our 
findings thus are conservative; they may understate the size of the negative effect.

A number of international pairs of locations involve inland centers such as Cincinnati or Uppsala. In those cases, international transport involved a mixture of land and sea shipping. By including all international pairs, then, we may underestimate the scale of the (negative) ocean effect. However, we do not have data on shipments that would allow us to refine these measurements and, as noted earlier, direct trade between the US and Sweden was relatively limited..$^{9}$

There are also reasons to expect differences across goods in price dispersion and for these differences to relate to factors correlated with shipping costs and ocean effects. This heterogeneity could arise due to perishability, value-to-weight ratios, and unobserved differences in official barriers to trade such as tariff and non-tariff barriers. We turn, next, to commodity-by-commodity results.

Of the 14 commodities available, we present results for those with at least 100 observations ( $j k$ pairs) and for which the $R^{2}$ is at least $10 \%$. The first criterion leads to our omitting copper, pig iron, salt, saltpetre, and wool. The second one leads to our omitting beef. Table 3 shows regression results for the remaining 8 commodities individually. Together these commodities span 3220 of the 3607 observations that were pooled in table 2. Again standard errors based on clustering by locations were very similar to heteroskedasticity-consistent ones, and so are not shown separately.

The commodity-specific distance effect, $\widehat{\beta}_{d i}$, is positive and significant at the $1 \%$ level for 6 of the 8 commodities and (marginally) negative in only one case. The ocean effect, $\widehat{\omega}_{o i}$, is negative and significant at the $1 \%$ level for 6 of the 8 commodities too. And it is of a similar magnitude for all of these, with point estimates from 3375 to $5619 \mathrm{~km}$. Taking the upper range of these point estimates would put the effective distance between Stockholm and Philadelphia at $826 \mathrm{~km}$, and within the standard error of estimation of Webster's 80 $\mathrm{km}$. So, it could be that his estimate was reasonable when inferred from a particular piece

\footnotetext{
${ }^{9}$ As Coleman (2007) notes, price differences may not identify transport costs with multiple locations in any case, so we do not try to interpret the ocean effect directly as a measure of relative transport costs.
} 
of anecdotal evidence he had at hand or he was selective in his choice of example to make his point. The evidence on whether internal Swedish dispersion is greater or less than what one would expect from that at similar distances within the United States is mixed at the commodity level.

It is intriguing to note that the two extreme slopes, those of wheat and butter, are also the extremes noted by Atack and Passell (1994, p 149, table 6.2) for transportation costs (circa 1815). They report transportation costs relative to price increase by a factor of 10 as we move from wheat to butter. Our coefficients on distance increase by a factor of about 7 .

In summary, we have found evidence of a positive role of distance in accounting for price dispersion, both in the pooled estimation and commodity-level results. The ocean effect is robustly negative, though not to the level implied by Webster's oratory. What remains unclear is how barriers to trade changed over time.

\subsection{Time-Varying Trade Barriers}

In a historical study spanning 130 years, it seems reasonable to expect improvements in transportation technology and infrastructure as well as disruptions of international trade (due to tariff wars or international conflict) to alter price dispersion over time. In this part of our analysis we include fixed time effects to allow flexibility in the rate of change of market integration.

To begin, the only new variable introduced is time itself. This can be thought of as exploratory data analysis, but an obvious advantage is that this covariate, time, is exogenous. In contrast, some economic variables that vary over time, such as tariffs, may not be exogenous to commodity-price dispersion. That is, if governments introduce tariffs when prices of foreign producers start to become competitive with those of domestic producers, overall price convergence may not arise due to these countervailing effects. Wars, in contrast, are not typically driven by international commodity price differentials and thus might be considered another source of exogenous variation in trade costs. But it can be difficult to know where

to draw the line among 18th-century wars that could have affected price differentials and 
distance effects. Our initial analysis uses decades and no doubt captures some of the effects of the Seven Years War and the Napoleonic Wars. The disadvantage of simply using time as a regressor is a loss of test power in assessing the effect of a specific event, such as a war or a particular technological change such as the expansion of railroads. But we have a lot of data, so this agnostic approach should detect both a trend to globalization and interruptions to that trend, whatever their causes.

Given our earlier findings we begin by controlling for distance and ocean effects in the same way, but now we use the absolute deviations directly (rather than their medians over time):

$$
a q_{i, j k, t}=\alpha_{i}+\beta_{d} \ln \left(d_{j k}+\omega_{o} D_{j k}^{o}+\omega_{s} D_{j k}^{s}\right)+\epsilon_{i, j k, t}
$$

Standard errors are clustered across locations and time to allow for residual correlation in these dimensions. This multiway clustering is recommended by Cameron, Gelbach, and Miller (2011) and Thompson (2011). And in this case these standard errors are larger than the traditional heteroskedasticity-consistent ones. The top line of table 4 contains results, now with 231,483 annual observations. We continue to find an overall effect of distance, measured by $\widehat{\beta}_{d}$, that is highly significant statistically and economically. And we continue to find a negative ocean effect and a positive effect within Sweden, as in sub-section 5.1.

Turning to the case in which fixed effects are included by adding 12 dummy variables, one for each decade from the 1740s to the 1850s, linearly (the 1730s serve as the omitted or reference decade), the specification becomes:

$$
a q_{i, j k, t}=\alpha_{i}+\alpha_{t}+\beta_{d} \ln \left(d_{j k}+\omega_{o} D_{j k}^{o}+\omega_{s} D_{j k}^{s}\right)+\epsilon_{i, j k, t}
$$

where $\alpha_{t}=1$ in a specific decade and 0 otherwise. ${ }^{10}$ Measuring the time-varying effects in this way allows for dispersion to increase or decrease with a wide range of patterns over time.

What is striking about the results using these time-varying measures of dispersion is that distance and commodity-specific fixed effects still dominate in terms of overall explanatory

\footnotetext{
${ }^{10} \mathrm{We}$ also interacted time dummies with the slope coefficient on distance and found no evidence of an interaction.
} 
power, the $R^{2}$ is 0.59 , even with no time-varying covariates (the first row of table 4 ) compared to 0.61 with time-varying effects. Note that the change is highly statistically significant (with an $F$-test statistic whose $p$-value is effectively 0.00 ), despite its small magnitude, given the very large number of observations.

Figure 6 graphs the estimated decade-effects, $\hat{\alpha}_{t}$, along with their $95 \%$ confidence intervals. Since the dependent variable is the absolute value of a relative price any reduction in the intercept from one decade to another represents a move towards zero, or price convergence. The value for the time dummy variable in the 1740 s is insignificantly different from the starting value of zero in the 1730 s, while all subsequent values are significantly below zero at the $1 \%$ level of significance. We see a history best described as convergence with an interruption. The decline in the intercept proceeds steadily from the 1740 s to the 1790 s then stalls and is reversed in the 1810s. Its value in the 1830s is only just below its value in the 1790s, suggesting a 30-40-year interruption, before convergence resumed steadily to the end of this sample in 1860 .

Table 5 shows the increases in explanatory power from adding decade effects to commodityspecific regressions. Omitted are commodities with fewer than 1,000 observations: copper, salt, and saltpetre. The explanatory power varies a great deal across commodities (as was true in table 3 for medians over time). For example, the third column shows that distance explains a lot of price dispersion for bar iron and pig iron, but very little for wax candles or wool. But in all cases the fourth column shows that adding decade effects leads to a large improvement in the statistical fit. In several cases - beef, pork, tallow, tallow candles, and wool - the $R^{2}$ more than doubles. Moreover, all of these improvements lead to $F$-statistics with very low $p$-values, given the large numbers of observations (not shown).

Jacks (2011) also reports an increase in price dispersion during the Napoleonic Wars with an overall declining trend, using grain prices within England from 1771 to 1815. Our finding uses a longer time span, two countries, and multiple commodities and presents a similar finding in a different context. The driving forces of the integration, however, are likely to be 
different if rail, canal and river shipping costs evolved differently from ocean shipping over time.

We also consider decade fixed effects that are specific to the three geographic categorizations (within the US, within Sweden, and cross-country pairs). The last set of results on time focuses on this geographic categorization, pooling all goods. That is, we consider the possibility that price dispersion was changing over time in some subsets of locations, but

not others. A number of the additional coefficients were significant at conventional levels of statistical significance, but jointly they were not. In other words, figure 6 continues to be a good summary of the overall time trend in dispersion.

\section{Conclusion}

We have explored price dispersion using more than 230,000 relative prices covering more than a century of data (and back well into the 18th century), from cities and towns in the United States and Sweden, and for 14 commodities. Deviations from the LOP differ substantially across commodities but there is a clear increase in price deviations as the distance separating city pairs rises. The ocean effect is large and negative, consistent with far greater trade frictions overland compared to by ocean, and also consistent with Daniel Webster's rhetoric in direction, if not magnitude. International price dispersion thus was much less than would be predicted based on national distances alone.

Evidence on the role of time is mixed. We stress two interesting things we did not find and one that we did. First, distance and ocean-crossing provide most of the statistical explanation for price dispersion even when time effects are included (as table 4 shows). Second, these effects are, surprisingly, quite stable over time. We did not find evidence for interaction between time and distance, for example, as one might expect. Third, however, the time effects show that, averaged over goods and locations, there was a statistically significant process of price convergence that began early and was broad-based. It was interrupted for 2-3 decades during the Napoleonic Wars, but otherwise unfolded from the 1730 s to the 
1850s. In contrast, the Stockholm-Philadelphia real exchange rate (shown in figure 2) shows no trend, a feature which thus illustrates the importance of studying individual prices.

\section{Appendix: Price Index Construction}

Detailed description of the method of price index construction as well as comparisons to other US and Swedish price index series may be found in Crucini and Sastry (2013). Following Edvinsson and Soderberg (for Sweden) and Officer (for the United States), we use the Laspeyres formula to construct price indices from common currency commodity prices:

$$
P_{0, t}=\frac{\sum_{i} P_{i, t} V_{i, 0}}{\sum_{i} P_{i, 0} V_{i, 0}}=\sum_{i} s_{i, 0} \frac{P_{i, t}}{P_{i, 0}}
$$

where $P_{t, i}\left(V_{0, i}\right)$ is the price (quantity) of commodity $i$ in year $t$ and the zero denotes a choice of base year. The second expression expresses the price index as the expenditure-weighted average of price ratios (current prices relative to base prices). The expenditure weights are expressed as time-invariant in the formula and measured at a base year.

The real exchange rate is constructed as the ratio of the Stockholm price index to the Philadelphia price index. Importantly, the same basket of goods is used in the construction of both indices. In particular, three different sets of weights are used, one for each of these time periods: 1733-1784, 1784-1803, 1803-1860. The choice of time periods was out of convenience to maximize the breadth of goods we could include in the basket given the available price observations in these two cities. The calculation of weights is somewhat arbitrary, but the general approach was to reallocate budget shares for goods not in our sample to very similar goods (e.g. barley to wheat) and, if necessary, rescale all weights to one. Table A1 gives the weights. 


\section{TABLE A1: CONSUMPTION EXPENDITURE WEIGHTS}

\begin{tabular}{cccc}
\hline \hline Commodities & $1733-1784$ & $1784-1803$ & $1803-1860$ \\
\hline Beef & 0.100 & 0.060 & 0.059 \\
Butter & & 0.269 & 0.265 \\
Cod & & 0.060 & 0.059 \\
Hops & 0.150 & 0.040 & 0.039 \\
Pork & & 0.090 & 0.088 \\
Tallow & 0.015 & 0.015 \\
Tallow Candles & & 0.008 \\
Wax Candles & & & 0.008 \\
Wheat & 0.750 & 0.468 & 0.460 \\
\hline Sum & 1.000 & 1.000 & 1.000 \\
\hline
\end{tabular}

Notes: Commodities excluded: Bar Iron, Copper, Hides, Lumber boards, Nails, Pig Iron, Salt, Saltpetre, Wool. At the points the weights change, the indices are linked by rescaling the "new" series to match the price level of the "old" calculation at the same point (e.g. the price level at 1784 using the $1733-1784$ weights.

\section{References}

[1] Atack, Jeremy and Peter Passell (1994) A New Economic View of American History: From Colonial Times to 1940 (Second Edition). W.W. Norton \& Co.

[2] Cameron, A. Colin, Jonah B. Gelbach, and Douglas L. Miller (2011) Robust inference with multiway clustering. Journal of Business and Economic Statistics 29, 238-49.

[3] Cole, Arthur Harrison (1938) Wholesale Commodity Prices in the United States, 17001861. Harvard University Press: Cambridge, MA.

[4] Cole, Arthur and Ruth Crandall (1964) The international scientific committee on price history. Journal of Economic History 24, 381-388.

[5] Coleman, Andrew (2007) The pitfalls of estimating transactions costs from price data: Evidence from trans-Atlantic gold-point arbitrage, 1886-1905. Explorations in Economic History 44, 387-410. 
[6] Crucini and Sastry (2013) Estimating U.S. Inflation from 1700 to 1861, Vanderbilt University mimeo.

[7] Dobado, Rafael and Gustavo A. Marrero (2005) Corn market integration in Porfirian Mexico. Journal of Economic History, 65, 103-128.

[8] Edvinsson, Rodney and Johan Söderberg (2010) The evolution of Swedish consumer prices, 1290-2008. chapter 8 in Rodney Edvinsson, Tor Jacobson, and Daniel Waldenström (eds.) Historical Monetary and Financial Statistics for Sweden: Exchange Rates, Prices, and Wages, 1277-2008. Stockholm: Sveriges Riksbank.

[9] Elsas, Moritz J. $(1936,1949)$ Umriss einer Geschichte der Preise und Löhne in Deutschland vom ausgehenden Mittelalter bis zum Beginn des neunzehnten Jahrhunderts. 2 vols. Leiden: A. W. Sijthoff.

[10] Friis, Astrid and Kristof Glamann (1958) A History of Prices and Wages in Denmark, 1660-1800. Vol. I. Longman, Green and Co., London.

[11] Gorodnichenko, Yuriy and Linda Tesar (2009) Border effect or country effect? Seattle may not be so far from Vancouver after all. American Economic Journal: Macroeconomics, 1, 219-41.

[12] Hamilton, Earl J. (1947) War and Prices in Spain, 1651-1800. Cambridge: Harvard University Press.

[13] Hauser, Henri (1936) Recherches et documents sur l'histoire des prix en France de 1500 à 1800. Paris: Les Presses Modernes.

[14] Head, Keith and Thierry Mayer (2013) What separates us? Sources of resistance to globalization. Canadian Journal of Economics 46, 1196-1231.

[15] Hung, Christian (2014) A Transportation Infrastructure Approach to Economic Distance, mimeo Vanderbilt University. 
[16] Jacks, David S. (2004) Market integration in the North and Baltic Seas, 1500-1800. Journal of European Economic History 33, 285-329.

[17] Jacks, David S. (2005) Intra- and international commodity market integration in the Atlantic economy, 1800-1913. Explorations in Economic History 42, 381-413.

[18] Jacks, David S. (2006) What drove 19th century commodity market integration? Explorations in Economic History 43, 383-412.

[19] Jacks (2009) On the death of distance and borders: Evidence from the nineteenth century. Economics Letters 105, 230-233.

[20] Jacks, David S. (2011) Foreign wars, domestic markets: England, 1793-1815. European Review of Economic History, 15, 277-311.

[21] Jacks, David S., Kevin H. O'Rourke, and Jeffrey G. Williamson (2011) Commodity price volatility and world market integration since 1700. Review of Economics and Statistics $93,800-813$.

[22] Jörberg, Lennart (1972) A History of Prices in Sweden 1732-1914. Volume I: Sources, Methods, Tables. Lund: CWK Gleerup.

[23] Keller, Wolfgang and Carol H. Shiue (2008) Tariffs, trains, and trade: The role of institutions versus technology in the expansion of markets. NBER Working Paper 13913.

[24] Klovland, Jan Tore (2005) Commodity market integration 1850-1913: Evidence from Britain and Germany. European Review of Economic History 9, 163-197.

[25] McCusker, John J. (1978). Money and Exchange in Europe and America, 1600-1775: A Handbook. (reissued with corrections, 1992). University of North Carolina Press: Chapel Hill.

[26] Officer, Lawrence H. (2006) Dollar-sterling parity: 1789-1978. Table Ee612-614 in Historical Statistics of the United States, Earliest Times to the Present: Millennial Edition, 
edited by Susan B. Carter, Scott Sigmund Gartner, Michael R. Haines, Alan L. Olmstead, Richard Sutch, and Gavin Wright. New York: Cambridge University Press.

[27] O'Rourke, Kevin and Jeffrey G. Williamson (1994) Late nineteenth-century AngloAmerican factor-price convergence: Were Heckscher and Ohlin right? Journal of Economic History 54, 892-916.

[28] Parsley, D. C., and S.-J. Wei (2001) Explaining the border effect: The role of exchange rate variability, shipping costs, and geography. Journal of International Economics 55, $87-105$.

[29] Pippenger, John and Llad Phillips (2008) Some pitfalls in testing the law of one price in commodity markets. Journal of International Money and Finance 27, 915-925.

[30] Posthumus, Nicolas W. (1946) Inquiry into the History of Prices in Holland. Vol. I: Wholesale Prices at the Exchange of Amsterdam, 1585-1914. Rates of Exchange at Amsterdam, 1609-1914. Leiden: E. J. Brill.

[31] Pribram, Alfred F. (1938) Materialen zur Geschichte der Preise und Löhne in Osterreich. Vienna: C. Veberreuters Verlag.

[32] Rogoff, Kenneth A., Kenneth Froot, and Michael Kim (2001) The law of one price over 700 years. IMF WP/01/174.

[33] Shiue, Carol H. (2005) From political fragmentation towards a custom union: Border effects of the German Zollverein, 1815 to 1855. European Review of Economic History $9,129-162$.

[34] Slaughter, Matthew J. (1995) The antebellum transportation revolution and factor price convergence. NBER working paper 5303. 
[35] Taussig, Frank William (1892) State Papers and Speeches on the Tariff. Speech of Daniel Webster Upon the Tariff, in the House of Representatives, April 1-2, 1824. Cambridge MA: Harvard University Press.

[36] Thompson, Samuel B. (2011) Simple formulas for standard errors that cluster by both firm and time. Journal of Financial Economics 99, 1-10.

[37] Trenkler, Carsten and Nikolaus Wolf (2005) Economic integration across borders: the Polish interwar economy. European Review of Economic History 9, 199-231. 
TABLE 1: CITY PAIRS BY COMMODITY

\begin{tabular}{ccccc}
\hline \hline Commodity & units & UU & SS & SU \\
\hline bar iron & ton & 13 & 54 & 62 \\
beef & barrel & 6 & 205 & 84 \\
butter & $\mathrm{lb}$ & 10 & 480 & 150 \\
copper & $\mathrm{lb}$ & 5 & 0 & 4 \\
hops & $\mathrm{lb}$ & 3 & 243 & 60 \\
pig iron & ton & 6 & 6 & 16 \\
pork & barrel & 13 & 190 & 116 \\
salt & bushel & 7 & 0 & 4 \\
saltpetre & $\mathrm{lb}$ & 6 & 0 & 4 \\
tallow & $\mathrm{lb}$ & 10 & 291 & 113 \\
tallow candles & $\mathrm{lb}$ & 2 & 406 & 62 \\
wax candles & $\mathrm{lb}$ & 6 & 405 & 116 \\
wheat & bushel & 8 & 291 & 115 \\
wool & $\mathrm{lb}$ & 3 & 10 & 15 \\
\hline Maximum city pairs & & 15 & 496 & 192 \\
\hline
\end{tabular}

Notes: A ton is 2000 lbs; a barrel is 217 lbs. The volumes are dry level bushels. To convert to metric units, a lb is $0.45359 \mathrm{~kg}$; a bushel is 0.35239 hectolitres. The notation UU refers to city pairs within the US, SS refers to city pairs within Sweden and SU refers to city pairs that lie across the ocean. 


\section{TABLE 2: BORDER REGRESSIONS 1732-1860 POOLED DATA}

$$
m d a q_{i, j k}=\alpha_{i}+\beta_{d} \ln \left(d_{j k}+\omega_{o} D_{j k}^{o}+\omega_{s} D_{j k}^{s}\right)+\epsilon_{i, j k}
$$

\begin{tabular}{lccccc}
\hline \hline Intercepts & $\widehat{\beta}_{d}$ & $\widehat{\omega}_{o}$ & $\widehat{\omega}_{s}$ & $R^{2}$ & $N$ \\
\hline \multirow{2}{*}{$\alpha_{i}$} & $9.91^{* * *}$ & $-3761.0^{* * *}$ & $183.8^{* * *}$ & 0.75 & 3607 \\
& $(1.25)$ & $(355.3)$ & $(67.0)$ & & \\
& & & & & \\
$\alpha$ & $9.28^{* * *}$ & $-3287.5^{* * *}$ & $135.7^{* *}$ & 0.21 & 3607 \\
& $(1.34)$ & $(613.3)$ & $(58.5)$ & & \\
\hline
\end{tabular}

Notes: Distance is in kilometres. The dummy variable $D_{j k}^{o}$ is 1 when $j$ and $k$ are on opposite sides of the ocean and 0 otherwise. The dummy variable $D_{j k}^{s}$ is 1 when $j$ and $k$ are both in Sweden and 0 otherwise. Standard errors are robust to heteroskedasticity (found using method $\mathrm{HC} 2)$. The asterisks $* * *, * *$, and * denote $p$-values less than $0.01,0.05$, or 0.10 respectively. 


\section{TABLE 3: BORDER REGRESSIONS 1732-1860 COMMODITY-BY-COMMODITY}

$$
m d a q_{i, j k}=\alpha_{i}+\beta_{d i} \ln \left(d_{j k}+\omega_{o i} D_{j k}^{o}+\omega_{s i} D_{j k}^{s}\right)+\epsilon_{i, j k}
$$

\begin{tabular}{lccccc}
\hline \hline Intercepts & $\widehat{\beta}_{d i}$ & $\widehat{\omega}_{o i}$ & $\widehat{\omega}_{s i}$ & $R^{2}$ & $N$ \\
\hline Bar Iron & $15.33^{* * *}$ & 17257.1 & $333.4^{* *}$ & 0.78 & 129 \\
& $(5.59)$ & $(30184.4)$ & $(159.9)$ & & \\
Butter & $29.38^{* * *}$ & $-5254.9^{* * *}$ & 366.7 & 0.51 & 640 \\
& $(9.64)$ & $(276.4)$ & $(279.6)$ & & \\
Hops & & & & \\
& $16.50^{* * *}$ & $-5315.6^{* * *}$ & 49.0 & 0.40 & 306 \\
Pork & $(3.01)$ & $(164.7)$ & $(38.3)$ & & \\
& $5.73^{* * *}$ & $-5619.3^{* * *}$ & -8.4 & 0.25 & 319 \\
Tallow & $(0.73)$ & $(75.7)$ & $(20.8)$ & & \\
& & & & \\
Tallow Candles & $4.35^{* * *}$ & $-4177.9^{* * *}$ & $-18.4^{* *}$ & 0.27 & 414 \\
& $(0.63)$ & $(817.9)$ & $(8.6)$ & & \\
Wax Candles & 9.22 & $-3374.7^{* * *}$ & 748.8 & 0.36 & 470 \\
& $(7.05)$ & $(473.4)$ & $(887.3)$ & & \\
Wheat & $-19.95^{*}$ & $-4689.3^{* * *}$ & $8500.0^{*}$ & 0.18 & 528 \\
& $(11.67)$ & $(1374.1)$ & $(4733.7)$ & & \\
\hline
\end{tabular}

Notes: Distance is in kilometres. The dummy variable $D_{j k}^{o}$ is 1 when $j$ and $k$ are on opposite sides of the ocean and 0 otherwise. The dummy variable $D_{j k}^{s}$ is 1 when $j$ and $k$ are both in Sweden and 0 otherwise. Standard errors are robust to heteroskedasticity (found using method HC2). The asterisks $* * *, * *$, and ${ }^{*}$ denote $p$-values less than $0.01,0.05$, or 0.10 respectively. 


\section{TABLE 4: BORDER REGRESSIONS 1732-1860 POOLED DATA (WITH TIME EFFCTS)}

$$
a q_{i, j k, t}=\alpha_{i}+\alpha_{t}+\beta_{d} \ln \left(d_{j k}+\omega_{o} D_{j k}^{o}+\omega_{s} D_{j k}^{s}\right)+\epsilon_{i, j k, t}
$$

\begin{tabular}{lccccc}
\hline \hline Intercepts & $\widehat{\beta}_{d}$ & $\widehat{\omega}_{o}$ & $\widehat{\omega}_{s}$ & $R^{2}$ & $N$ \\
\hline \multirow{2}{*}{$\alpha_{i}$} & $11.2^{* * *}$ & $-4250.4^{* * *}$ & $178.6^{* * *}$ & 0.59 & 231,483 \\
& $(1.2)$ & $(296.3)$ & $(56.1)$ & & \\
& & & & & \\
$\alpha_{i}$ and $\alpha_{t}$ & $12.4^{* * *}$ & $-4346.2^{* * *}$ & $186.4^{* * *}$ & 0.61 & 231,483 \\
& $(1.4)$ & $(247.3)$ & $(58.2)$ & & \\
\hline
\end{tabular}

Notes: Distance is in kilometres. The dummy variable $D_{j k}^{o}$ is 1 when $j$ and $k$ are on opposite sides of the ocean and 0 otherwise. The dummy variable $D_{j k}^{s}$ is 1 when $j$ and $k$ are both in Sweden and 0 otherwise. Standard errors are clustered by time and location. The asterisks $* * *, * *$, and $*$ denote $p$-values less than $0.01,0.05$, or 0.10 respectively. 
TABLE 5: EXPLANATORY POWER OF DECADE EFFECTS

\begin{tabular}{lccc}
\hline \hline Commodity & $\begin{array}{c}\text { Restricted } R_{i}^{2} \\
\text { Distance }\end{array}$ & $\begin{array}{c}\text { Unrestricted } R_{i}^{2} \\
\text { Distance and Time }\end{array}$ & $N$ \\
\hline Bar Iron & 0.526 & 0.577 & 8022 \\
Beef & 0.036 & 0.078 & 19345 \\
Butter & 0.297 & 0.347 & 48051 \\
Hops & 0.123 & 0.223 & 23464 \\
Pig Iron & 0.780 & 0.831 & 1680 \\
Pork & 0.064 & 0.136 & 25947 \\
Tallow & 0.070 & 0.208 & 31278 \\
Tallow Candles & 0.064 & 0.152 & 24724 \\
Wax Candles & 0.009 & 0.018 & 26996 \\
Wheat & 0.193 & 0.233 & 19209 \\
Wool & 0.003 & 0.213 & 1319 \\
\hline
\end{tabular}

Notes: Each entry in the table reports the explanatory power of the regressions of the form reported in table 4, but allowing for commodity-specific coefficients. The first column excludes decade fixed-effects while the second column includes them. 
Figure 1: Price Indexes in Philadelphia and Stockholm

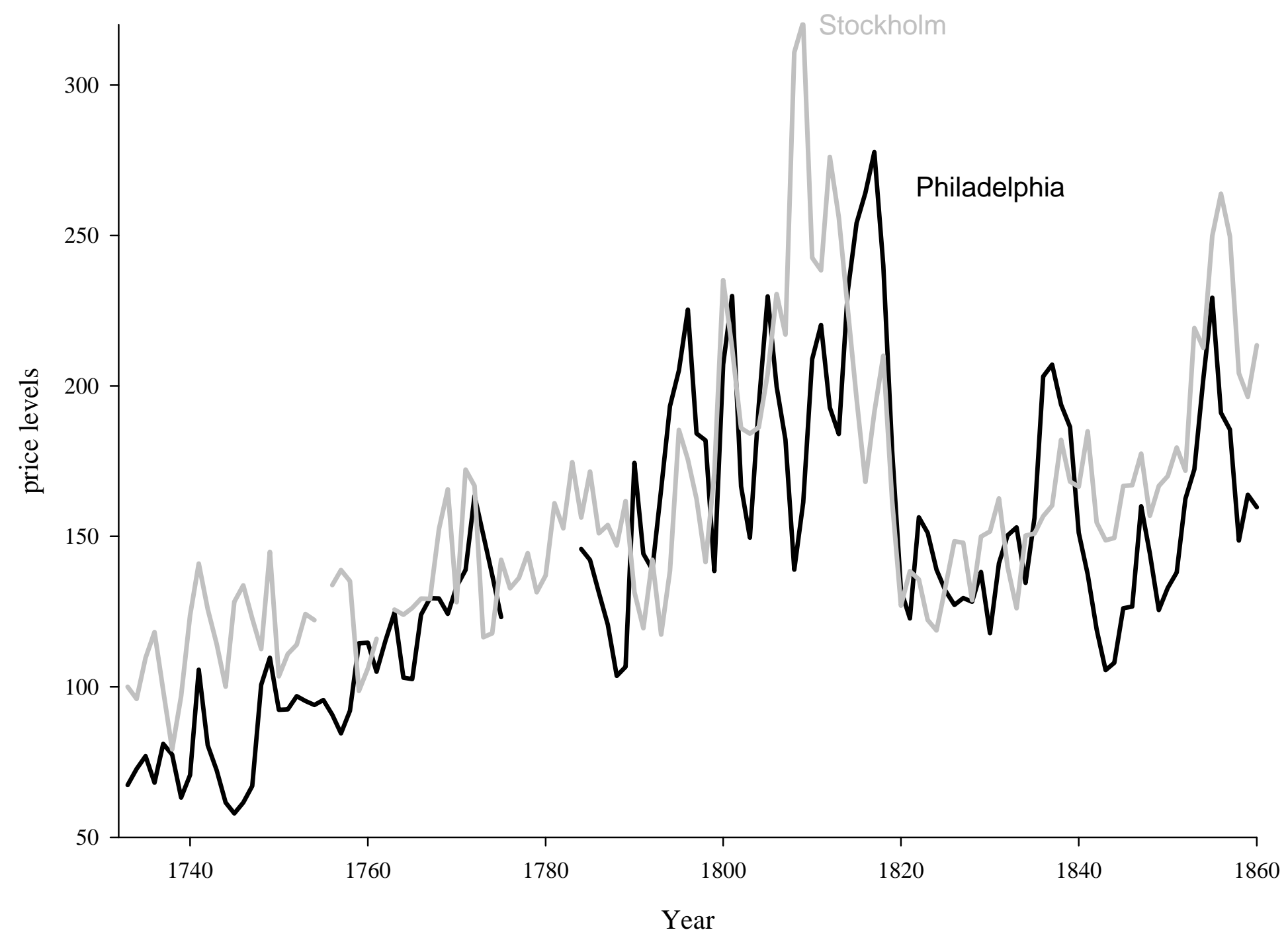

Notes: The price level is an index of prices in pounds sterling, normalized to 100 in Stockholm in 1733. The indexes are Laspeyres formulas with a common basket given in the Appendix. 
Figure 2: Real Exchange Rate Between Philadelphia and Stockholm

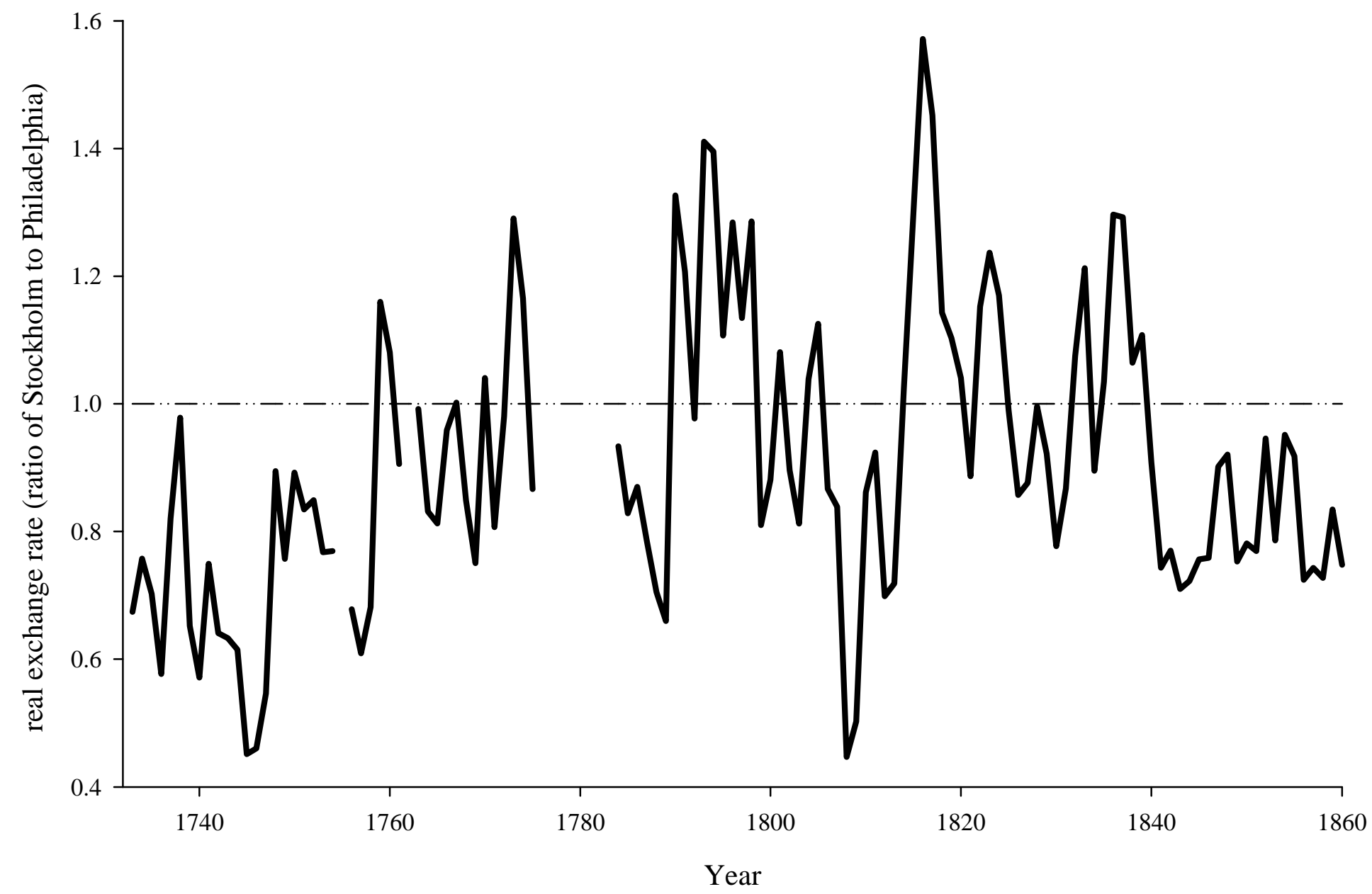

Notes: The real exchange rate is the ratio of the price index in Stockholm to the price index in Philadelphia. Price indexes, shown in figure 1, are of the Laspeyres form with common weights given in the Appendix. 


\section{Figure 3: Beef Prices}

\section{Sweden}

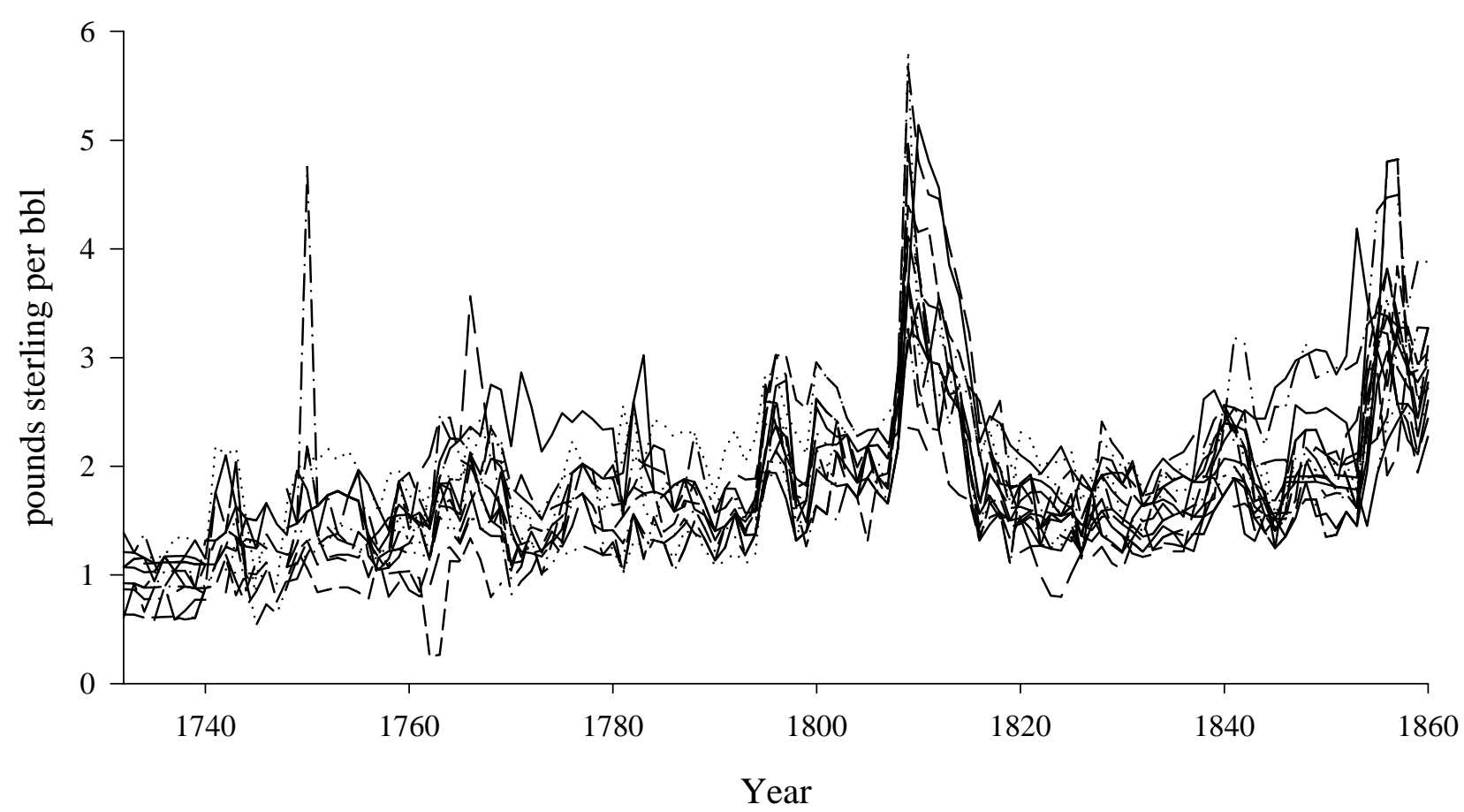

\section{United States}

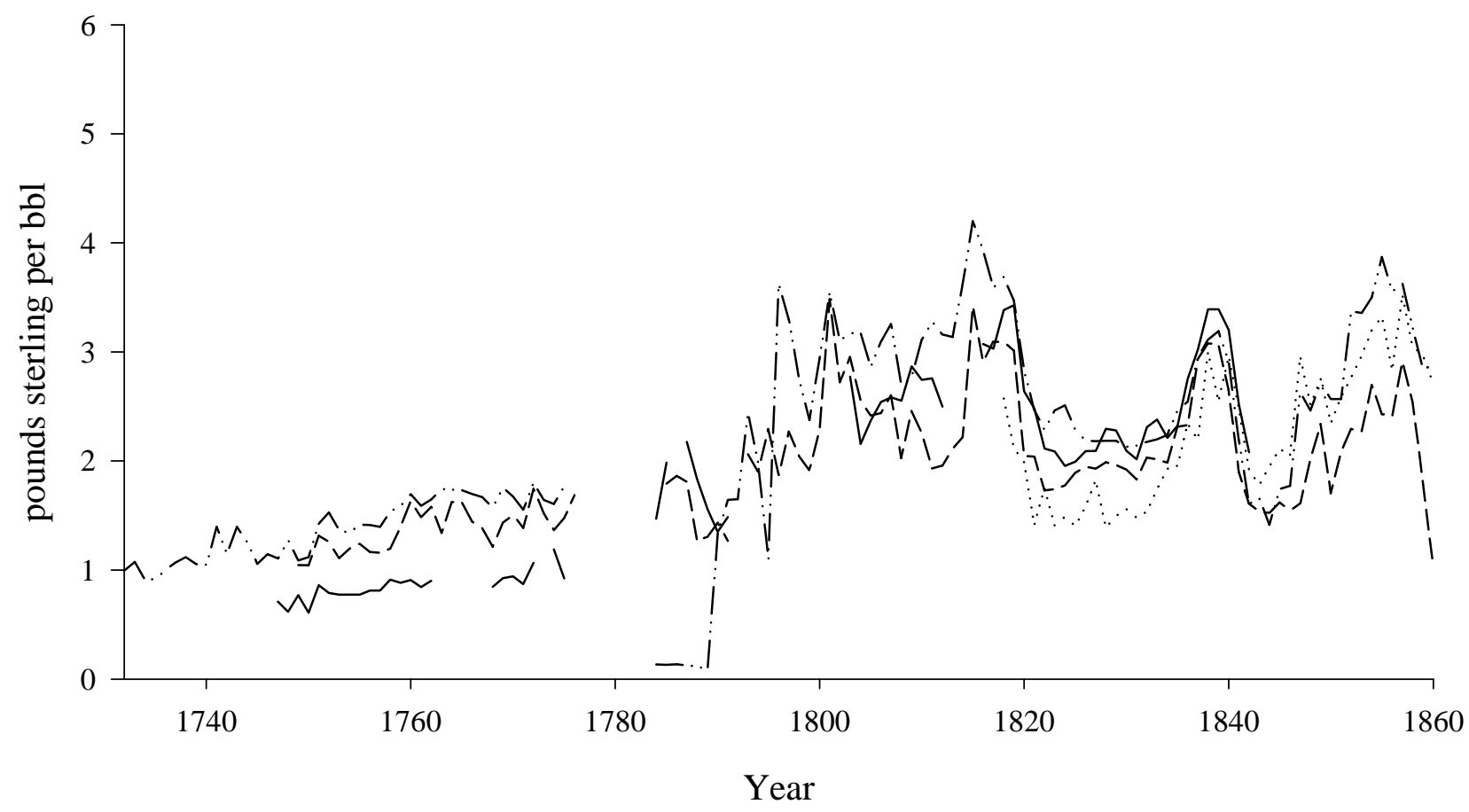

Notes: Prices are for 32 Swedish market towns, from Jorberg (1972), and for 6 US cities, from Cole (1938). All prices are in pounds sterling per barrel. 
Figure 4: Wheat Prices

Sweden

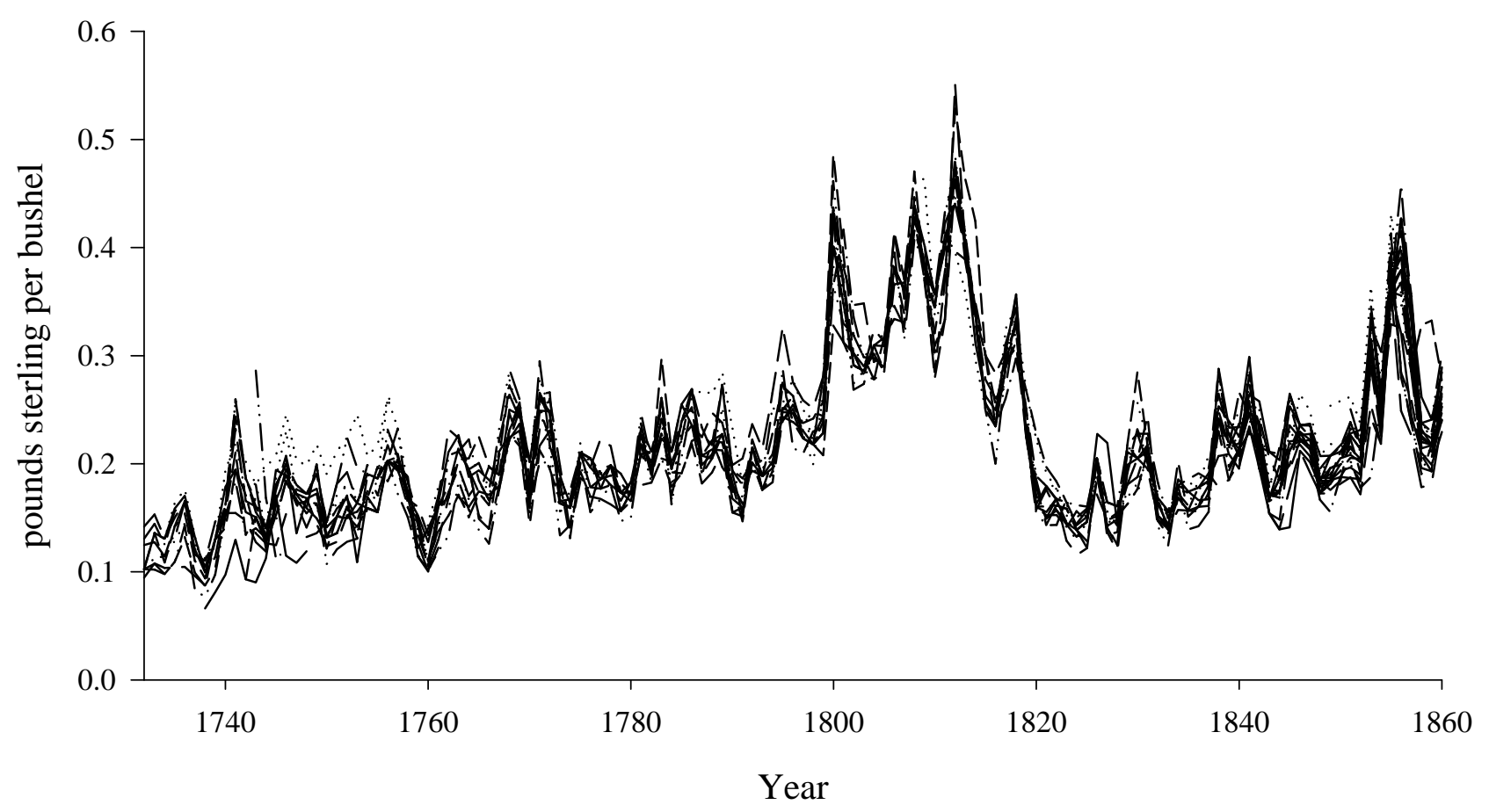

\section{United States}

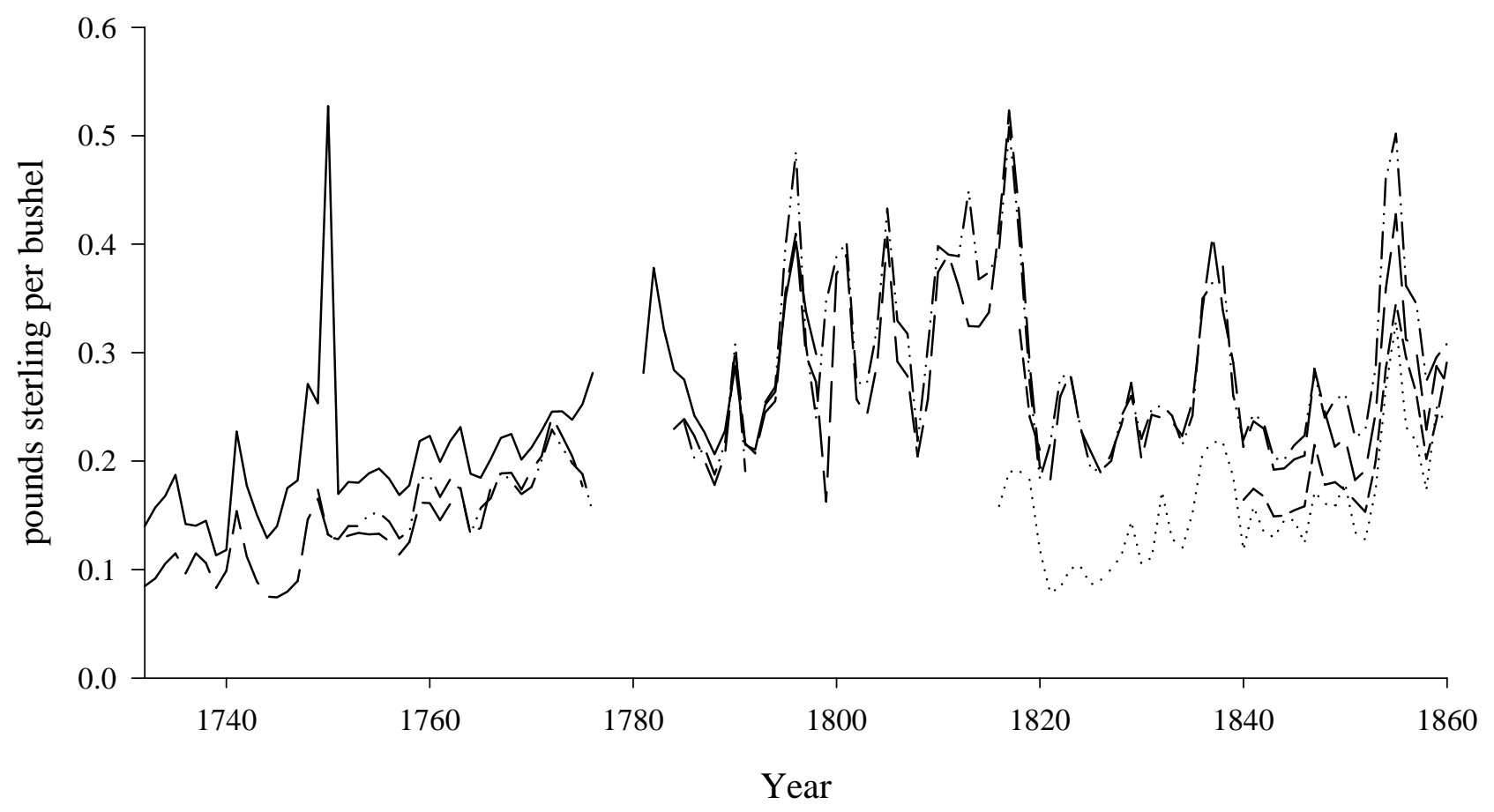

Notes: Prices are for 32 Swedish towns, from Jorberg (1972), and 6 US cities, from Cole (1938). Prices are in pounds sterling per bushel. 
Figure 5: Median Absolute Deviations

United States

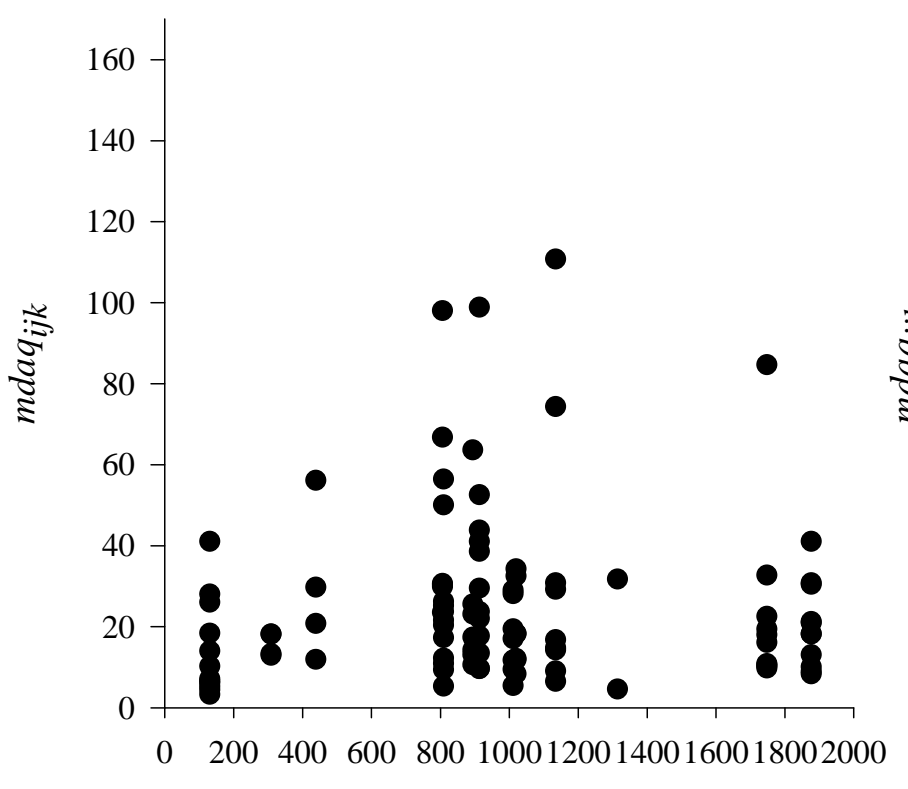

distance
Sweden

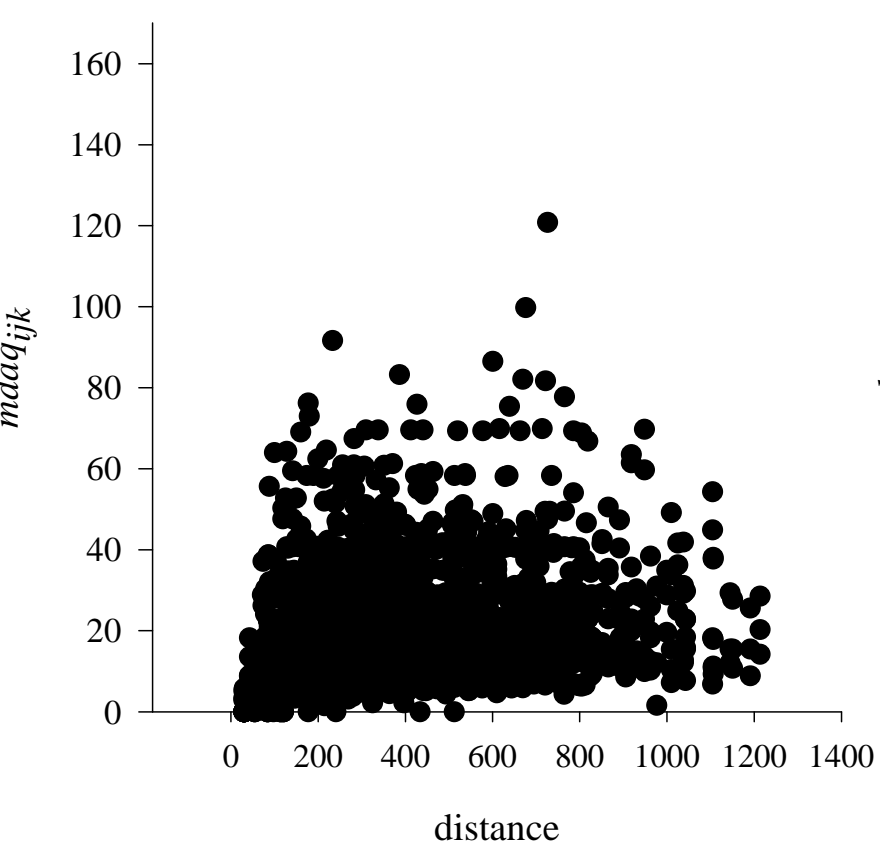

International

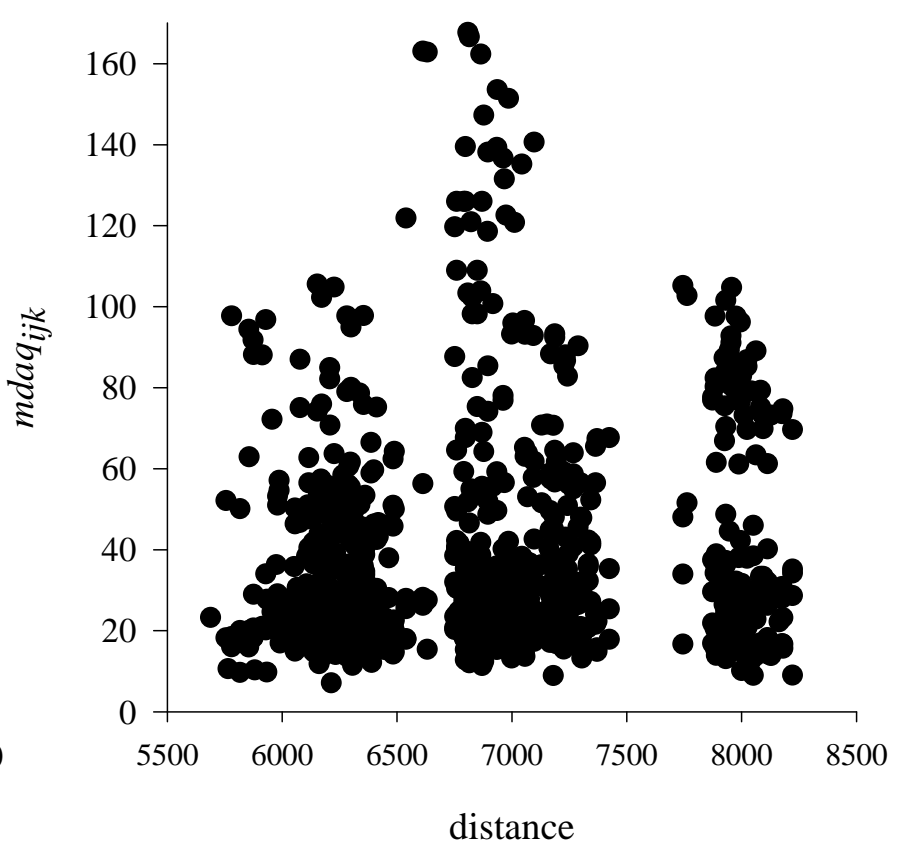

Notes: Observations are medians over time of percentage absolute values of log price differences for 14 commodities. Locations are 6 US cities and 32 Swedish towns. Distance is measured in kilometres on a great circle. 


\section{Figure 6: Declining Dispersion}

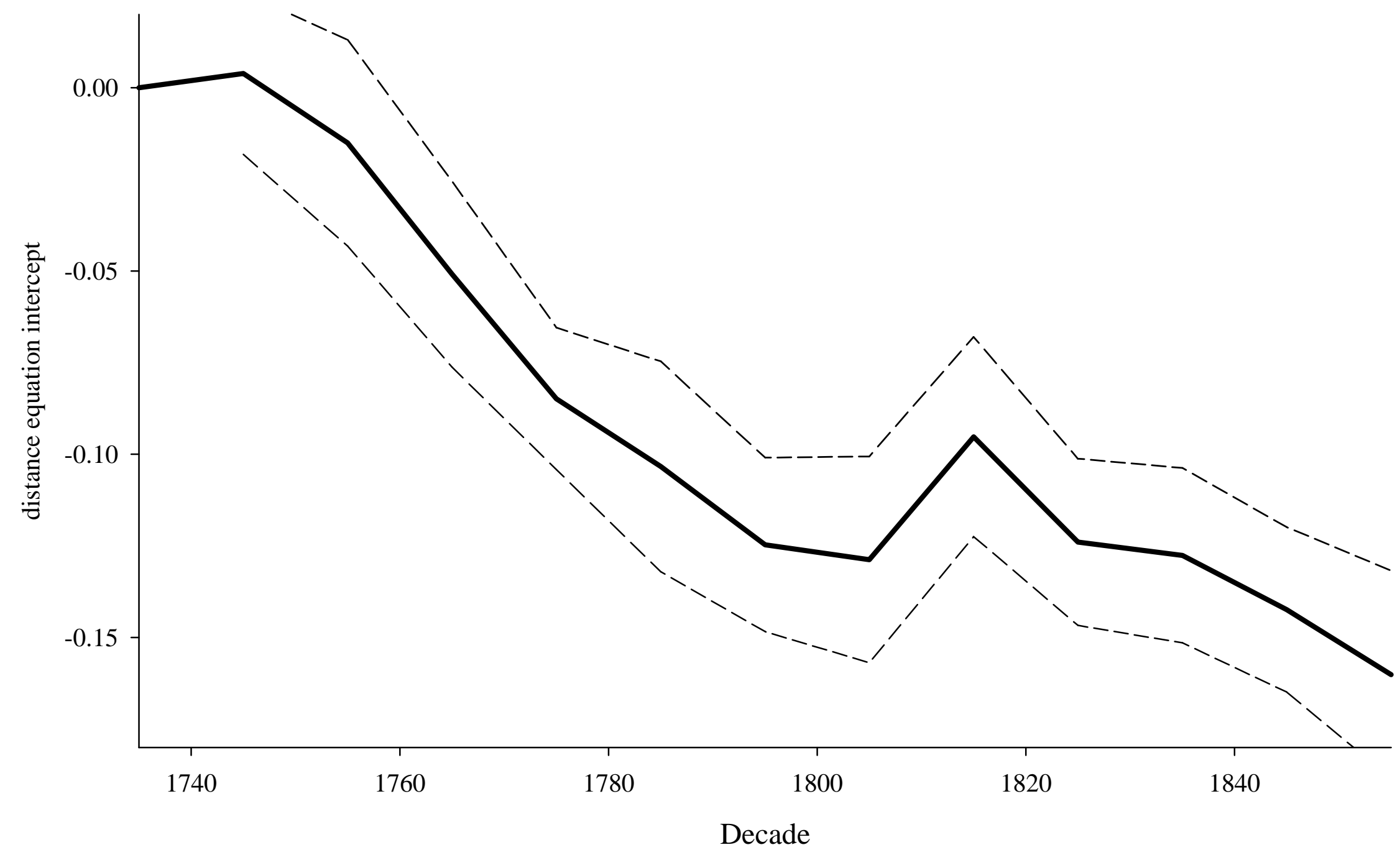

Note: The solid line connects the dedade-specific intercepts $\alpha_{t}$ from equation (5.7). The dashed lines show the $95 \%$ confidence intervals based on double-clustered standard errors. 